\title{
LIMITS OF POWER. CLERICAL APPOINTMENT AS PART OF DOMESTIC POLICY IN SWEDEN AFTER THE REFORMATION, 1560-1611
}

\author{
MikKO HILJANEN* \\ University of Jyväskylä
}

\begin{abstract}
This article examines state-church relations in Sweden by analysing clerical appointment processes in the latter part of the 16th century. The aim is to ascertain whether the king of Sweden could appoint pastors independently, and if not, with whom he was compelled to share the power. Earlier studies argue that the power of the king grew due to the reformation. First, this article examines the number of clerical appointments that were made in the period 1560-1611. The results reveal a remarkable annual variation in the number of clerical appointments. Second, the timing and share of clerical appointments made by the king are studied. The number of appointments made by the king is viewed against the total number of clerical appointments so as to reveal the importance of appointments made by the crown. Third, the article examines the proportion of appointments made by other au-thorities. The results suggest that the crown's role in clerical appointment processes varied, but more interestingly, it was not as ubiquitous as earlier researchers suggest. Thus article concludes that crown's power over the church in 16th century Sweden was not as vast as it has previously been claimed.
\end{abstract}

KEY WORDS: reformation, counter-reformation, state-church relation, confessionalization, clerical appointment process

\section{Introduction}

Compared to central Europe, the Reformation in the northern parts of Europe was not a popular movement, but was initiated and controlled by the Crown. Due to the nature of the Reformation in Sweden, it did not have as strong religious undertone, but at an early stage was tied to the Crown's interest in gaining political power and improving the economy of the state. The Reformation, especially during the first decades of Gustav Vasa's reign, was a way for the King to reduce the political power and economic resources of the Church (e. g. Holmquist 1933: 97-100; Heldtander 1955: 15-16; Sahndahl 1966: 39; Karonen 2014: 72-77; Nyman 2009: 37-38). 
The aim of this article is to study the dominance of the Crown over the Church after the Reformation. Due to the characteristics of the Reformation in Sweden, the Church, parishes and their leaders (bishops, pastors and the most important secular parishioners) were not entirely willing to submit to the power of the Crown, nor were they forced to do so. The integration of state and Church was more or less based on negotiation and the strength of the integration varied temporarily (Hiljanen, forthcoming). In this article, I argue that in practice the state and the Crown extended their power to the domain of the Church and to the local level of society (i. e. the parishes) by appointing pastors. By controlling the appointment process, the King could on the one hand fill the posts with men who were loyal to him; on the other hand the Crown could control the members of the estate of clergy, which was in the process of formation in the 16th and 17th centuries. Thus the clerical appointments were important from both ecclesiastical and governmental perspectives. Hence, in order to ascertain if the Church became dependent on the Crown in practice one needs to conduct an investigation of the share of pastoral appointments made by the King (or other authorities ${ }^{1}$ ).

The clerical appointment process is among the major research topics that scholars-especially church historians-have studied in Sweden and Finland. Many studies concentrate specifically on the influence of the Reformation on the process. For example, the Finnish historian K. A. Appelberg's dissertation (1896) concerns clerical appointments, especially in Finland, from the Reformation to the 17th century. The Swedish historian Hjalmar Holmquist published an article in 1933 discussing the topic throughout the realm. Other studies on the clerical appointment process have concentrated on the 17th and especially 18th centuries (see for example Heldtander 1955; Laasonen 1983; Hernroth 1989; Lindström 2002; Lindström 2003). In addition, some of the studies approach the theme from the perspective of social history (see Matinolli 1955; Sahndahl 1966). According to these historians, the Reformation increased the Crown's power over the Church which lost its independent status. However, the Crown's increased power was not an unassailable truth: it varied, especially after the reign of Gustav Vasa, when his sons vied with each other for the Crown (Holmquist 1933: 121, 127-128; Sahndahl 1966: 42; Paarma 1980: 379).

Clerical appointments have also been examined in Central and Western Europe. For example, Ronny Po-Chia Hsia (1989) and Bruce Tolley (1995) studied the social background of pastors in post-Reformation Germany. Both concluded that after the Reformation, most of the pastors were recruited from the middle of social strata: from the estate of burghers. Only the minority of pastors

1 The term 'other authority/authorities' in the Swedish context refers to persons who could appoint pastors by virtue of their position in the government or in the Church. These persons were primarily bishops, but in Sweden dukes as well as noble office-holders could sometimes appoint pastors. 
were the sons of nobles or peasants. Moreover, fairly soon after the Reformation the clergy formed a social group from which new pastors were recruited (Po-Chia Hsia 1989: 14-16, 179; Tolley 1995: 11-15). John McCallum studied the social background of Scottish ministers after the Reformation. He noted that in Scotland reformed ministers were fairly old and well educated. The turnover was quite low: once a clergyman was appointed to his living he stayed there (McCallum 2010: 122-123, 130-131). As these studies illustrate, the point of departure has been related to social history: historians have been interested in the social and geographical background of pastors, while studying the political connections has received less attention.

In general, the relations between church and state have been studied in terms of the confessionalization paradigm. According to this, both religion and politics and church and state were interwoven in the early modern period. Thus the Reformation did not only affect religion, but also caused political changes. One aspect of confessionalization is that it promoted the state-building process: Due to the rise of new confessions emerging in the Reformation, the Church and the geographical states merged because confessions (Catholicism, Lutheranism, and Calvinism) and geographical states needed each other in their struggles with other confessions and states. In this process the Church came under the control of the head of the geographical state. Especially in countries which had embraced Lutheranism (such as Sweden), the Church became one of the state's organizations where the head was a secular authority (Po-Chia Hsia 1989: 18-19; Schilling 1992: 208-210, 236, 242-243; Reinhard 1999: 172, 183-185, 186-189; see also Montgomery 1972: 28, 403). The confessionalization paradigm is best known in German-speaking Europe; in northern Europe only a few studies have applied it (Czaika 2007: 74). However, before the breakthrough of the paradigm, similar questions concerning the relationship between politics and religion were asked in northern Europe (see Montgomery 1972). Yet, within the space of few years, the paradigm has been introduced in numerous studies in the Nordic countries (Asche and Schindling 2003; Brilkman 2013; Hansen, Heisedal Bergesen, and Hage 2014).

Even though the process of clerical appointment has been studied almost exhaustively, the results, especially in the Swedish context, need to be re-assessed. First, these studies do not analyse clerical appointments in relation to the political and religious reality of the past, but examines the process and numbers of appointments per se (Lindström's studies are an exception). Second, the number of clerical appointments made by the King has been studied in absolute numbers, which is not very informative. This article studies the number of clerical appointments that the King (and other authorities) made vis-à-vis the total appointments made. This method reveals the share of appointments made by the King and the power struggle within the Church. In addition, compared to other studies on the process, this article sets the clerical appointments in the pan-European context as it ties the appointments, for example, to the Counter-Reformation. 
More specifically, this article studies the number of clerical appointments during the latter part of the 16th century in the diocese of Turku. Second, the share of appointments made by the Crown of all appointments is examined. The aim is to ascertain the annual proportion of appointments made by the King and the variation in this share over time. In addition, this article studies how the shares of appointments made by other authorities varied over time and how it was related to the share of the appointments made by the Crown. All in all, the main task is to assess the role of clerical appointments in policymaking during the era studied. The results do not only shed light on the Crown's opportunities to intervene in ecclesiastical policy, but also illustrate the political situation during the turbulent latter part of the 16th century.

The argument concerning the role of the clerical appointments in the power struggle in the realm is based on one strong premise that needs to be appraised. One might ask whether the number of clerical appointments illustrates the Crown's desire to take control over the Church. In other words, was the control of clerical appointments a way for the Crown to bend the Church under its will? Did the control over the clerical appointment process play any role in the wider sphere of governance? There is neither unambiguous answer to these questions, nor evidence confirming the premise, but it is an indisputable fact that the Crown claimed control of clerical appointments during the century. For example, in the 1560s the Crown used pastors' salaries as a means of leverage: the bailiffs refused to pay the pastors their salaries if they could not show the letter confirming their appointment by the Crown. Thus pastors were compelled to get confirmation even if they had been appointed by some other authority, for example by a bishop. Later, in the 1570 s, John III used clerical appointments as a means to promote liturgical reforms, as will be shown below (Appelberg 1896: 62-63, 68, 84-85; Holmquist 1933: 108-112; Heldtander 1955: 18; Paarma 1980: 367, 369, 371-375; see also Hiljanen, forthcoming). These examples illustrate that the control of clerical appointment processes was indeed important to the Crown; at least the monarch felt the need to be in charge of it.

This article is based on my recently formed database of the clergy (CDB 2015). Information for which was collected from various sources. The main source concerning the number of clerical appointments and the person making the appointment that has been used here is a compilation called Turun hiippakunnan paimenmuisto 1554-1721. This Paimenmuisto (Herdaminne in Swedish; Pfarrerbuch in German) is a register of clergymen. In Sweden and Finland these registers consist of short studies. The extent of information varies quite a lot: sometimes there is only a name and the year when the pastor was appointed, while in some registers there is also general information, for example, on the family and the lives of the clergy (Väänänen 1989: 175-176).

First of all I counted all clerical appointments made in the period 1560-1611. Then I searched all appointments with information about the timing and the per- 
son who made the appointment. ${ }^{2}$ Next I compared the total appointments made by the Crown (and other authorities) to all appointments made that year. During this process, I made a few simplifications: normally the appointment was made by issuing a letter of appointment (called a collation) to the person who was about to be appointed. However, sometimes a person had worked in the parish before receiving the official appointment-i. e. the year when his work commenced and the year when the collation was issued were not the same. These cases make the calculations more complicated. In this article, I have taken the first year of the pastors' incumbency as a benchmark and assumed that the collation was issued that year. Even if this does not reflect the reality, these cases are a minority of all known appointments, so they do not change the overall of the numbers and shares of the appointments made. In addition, it is noteworthy that the person appointing the pastor is not always known, as will be seen below. However, the cases when that person was the King are fairly well known because the collation was important to the recipients and on the other hand, the information is also preserved in the official documents.

The geographical area covered by this study is the major part of the territory of modern Finland. During the early modern period Finland was an eastern part of the Swedish kingdom, which separated in 1520s from the Danish-led Kalmar Union in a rebellion led by Gustav Vasa. The historian Jason Lavery has characterized 16th century Finland as a frontier of the Reformation. He argues that as a typical frontier area, Finland did not have a strong administrative system, which was to be built in the 16th and 17th centuries. Furthermore, the Reformation reached Finland slowly: the main ideas of the Reformation came from outside and were applied according to local conditions (Lavery 2012: 66-67).

To be more precise, the area studied covers the Diocese of Turku. It was the oldest, largest and westernmost of the two dioceses in Finland (the other was the Diocese of Vyborg, which was founded in 1554, when the Diocese of Turku was divided). The area studied contained the oldest population centres in Finland. In addition, the oldest and most important city at that point, Turku, was located there. The ecclesiastical and secular governments of the eastern part of Sweden were located in the city (Paarma 1980: 25-27; Nummela 2003: 136-141; Karonen 2014: 25-30). All in all, the area was on the periphery of Christendom and Europe, but the King of Sweden tried to take it under his power during the 1500 s. enable the confirmation of the information. Most important of these additional sources is Jukka Paarma's dissertation on the chapter of the diocese of Turku noting the appointments made by the bishops of Turku. It should be noted here that K. G. Leinberg also collected information about clerical appointments from original documents and published it in a series entitled 'Handlingar rörande Finska kyrkan och presterskapet'. 
The research period (1560-1611) was a turning point in Swedish history. Gustav Vasa died in 1560 and his eldest son, Erik XIV, took over the throne. However, before his demise, Gustav Vasa enfeoffed parts of the kingdom to his younger sons. Even if the purpose of the arrangement of the late King was to ensure the hegemony of the Vasa family at the head of the Swedish realm, in reality the duchies functioned as political divider because the dukes could and did implement their own policy in their duchies even if this was forbidden. Both Duke John (of Finland) and especially Duke Charles (of Södermanland) executed a coup d'état resting on their ducal status (Hedberg 1995: 43-47; Lappalainen 2009: 2627; Hedberg 2009: 221-222; Karonen 2014: 92-98). All in all, the era is characterized by an almost constant political struggle between the King (and his descendants) and the dukes. It culminated in the 1590s in a civil war and a purge of the nobles and other governmental agents thereafter. Religion played a crucial part in the turmoil: for example Duke Charles started a revolution partly because he did not share the religious standpoint of the lawful King.

\section{Pastoral Appointments}

In 1560-1611 altogether 267 individuals were appointed as pastors. The number of appointments varied quite a lot annually; the maximum number being 12 (1581) and the minimum 0 (1594 and 1598) (see Figure 1). The average was about 5.13 per year, median 5. This annual variation is interesting: why did the numbers vary so much? The information on the clergymen's careers suggests that the main reason for the variation is longer careers during the 1580 s which tended to occupy all the livings available so that the new generation of clergymen ordained during the 1590s could not be appointed and the number of new appointments diminished (CDB 2015). This, however, is not the only explanation: the turbulent domestic political situation of the realm during the 1590 s also affected the clerical appointments, as is shown below.

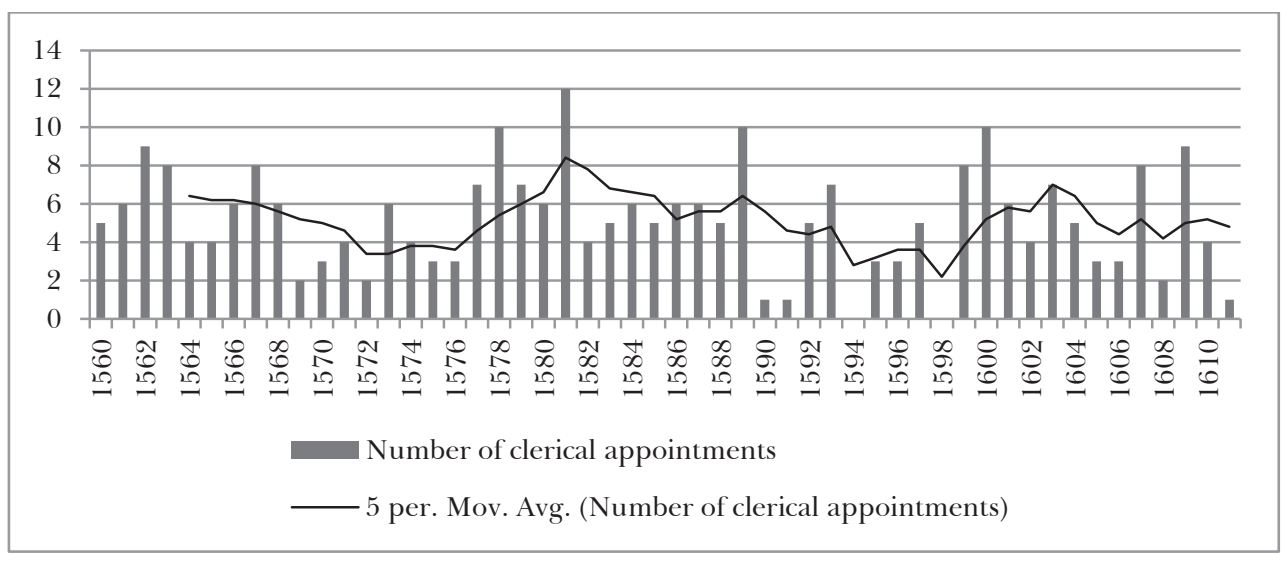

Figure 1: Number of clerical appointments. Source: CDB 2015. 
During the period studied altogether 41 (cca. 15\%) of pastors were appointed by the monarch and 33 (cca. 12\%) pastors were appointed by other authorities. It is not absolutely certain how the other pastors obtained their appointments. Presumably the role of the most important parishioners (richest peasants etc.) was important, as they played an important role in the appointment process during the Middle Ages (e. g. Appelberg 1896: 2-3; Holmquist 1933: 127-128). One has to keep in mind in assessing the results of this article that they are based on the cases where the person making the appointment could be identified (that is ca. $28 \%$ of all appointments made).

Figure 2 reveals significant differences between the monarchs. The number of appointments made by John III (29) is much higher than those made by his brothers (Eric XIV 4 appointments, Charles IX 8 appointments) and his son, Sigismund, who did not appoint any pastors during his reign as monarch of both Poland-Lithuania and Sweden. Appointments made by other authorities fell short of the number of appointments made by monarchs during the reigns of John III and Charles IX, but exceeded the numbers of appointments made by Eric XIV and Sigismund.

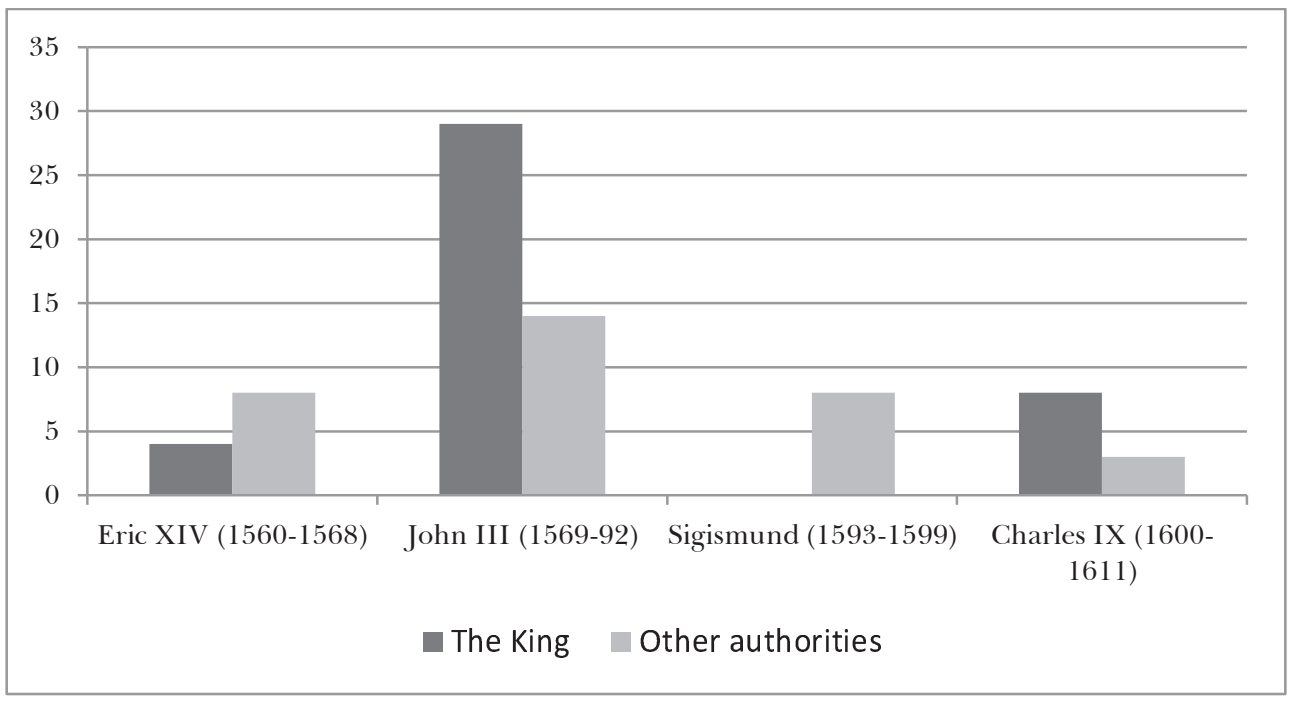

Figure 2: Absolute number of clerical appointments made by the King and other authorities. Source: CDB 2015.

According to the Swedish historians Tore Heltander and Martin Sahndahl, along with Gustav Vasa, John III was the most active King in terms of appointing the pastors (Heldtander 1955: 21; Sahndahl 1966: 39-42). Figure 2 confirms this conclusion. However, as already noted, the absolute numbers do not exactly reflect the relevance of the appointments made by the King. To be more precise, as seen in Figure 1, the number of clerical appointments varied widely for each year; pre- 
sumably appointments made by the King were not so significant when numerous pastors were appointed. Hence the number of appointments needs to be contextualized to show the real significance of pastoral appointments made by the King.

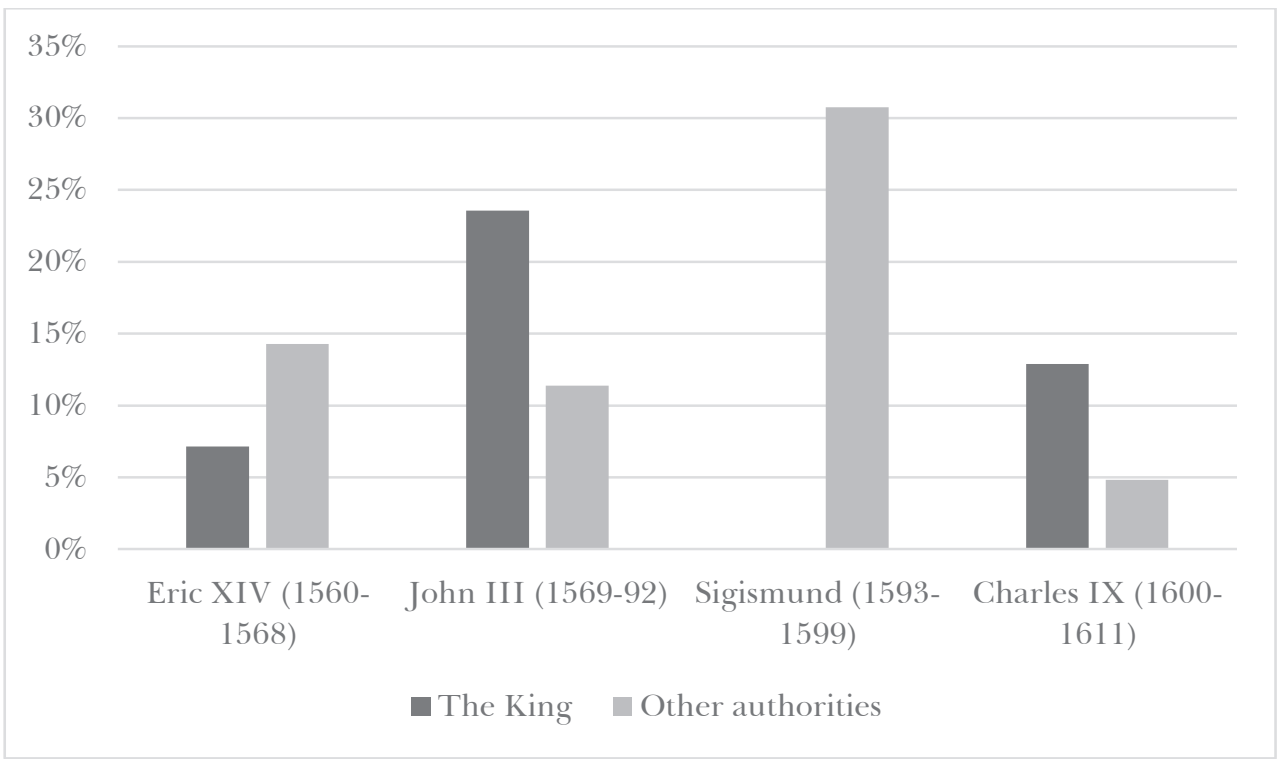

Figure 3: The share of clerical appointments made by the King and other authorities of all appointments. Source: CDB 2015.

Figure 3 sets the appointments made by other authorities and the Kings of Sweden against the background of all the appointments made during the reigns of the respective monarchs. Compared to the absolute numbers of appointments, the pattern remains the same: John III was the most active among the kings of Sweden. He appointed $24 \%$ of all pastors appointed in Finland during his reign; Eric XIV appointed $7 \%$ and Charles IX 13\% of all pastors appointed in their reigns. From the proportions of appointments made by other authorities, Sigismund's reign stands out. At that time more than a third of the pastors were appointed by some authority other than the monarch-although it must naturally be kept in mind that Sigismund did not appoint any pastors, but still the share is decidedly large.

What does the share of the clerical appointments made by the King tell about the limits of the power of the Crown? Did the Church defer to the King or did it retain its independent status? The share of clerical appointments made by the King, cca. 15\%, does not appear high, and it suggests that the King did not control the Church or at least its agents at local level of society-the pastors. However, the number of appointments made by other authorities-including the Bishop of Turku-is even lower (cca. 12\%). Comparing these proportions suggests that the 
King enjoyed greater power in this than the other authorities, even if the proportion of appointments made by the King is rather small.

Yet not all the pastors in every parish were equally valuable to the King and the other authorities; i. e. some of the livings were more important than others. Important posts included, for example, administrative posts in the chapter (e. g. the bishop, the dean of the cathedral school and the pastor of Turku parish), because by filling these posts with men who were loyal to him the King could control the entire chapter of the Diocese of Turku and rely on that the chapter making decisions beneficial to the Crown. These livings were most sought after, for instance, in the 1590s when the realm was heading towards revolution (CDB 2015; see also Hiljanen, forthcoming).

On the other hand, the most important ecclesiastical posts benefitted the officeholder financially (Suolahti 1919: 175, 195-196, 248; Cederlof 1934: 328-329). Thus filling the important administrative posts was not just the King's strategy to bend the chapter and pastors to his will, but it was also important from the candidate's perspective because the clergy could improve both their finances and their careers by occupying these posts. The King and other authorities could use the eagerness of clerical candidates to obtain these posts as a means to promote their cause. For example, the King appointed some of the military pastors or chaplains to some of the parishes as a reward of their service in the army (CDB 2015; see also e. g. Hiljanen forthcoming).

All in all, I conclude that the appointments made by the King were not frequent to permit the claim that the King controlled the Church. However this conclusion needs to be studied more carefully. For example, the temporal variation in appointments made by the King or other authorities is interesting; after all, the variation in the numbers of clerical appointments was considerable. It may be that at the times the King had a tight grip on the Church and other times the other authorities held it.

\section{The Situation in Politics and Religion}

The variation across time in the numbers of the appointments by the King was considerable: in numerous years-especially in the 1590s the King did not appoint any pastors, while towards the turn of the 1570s and the 1580s the number is relatively high (CDB 2015). To analyse the reasons for this variation and also the King's dominance over the Church, these numbers need to be put into context. Figure 4 illustrates the ratio of the numbers of pastoral appointments made by the King and the total number of appointments. 


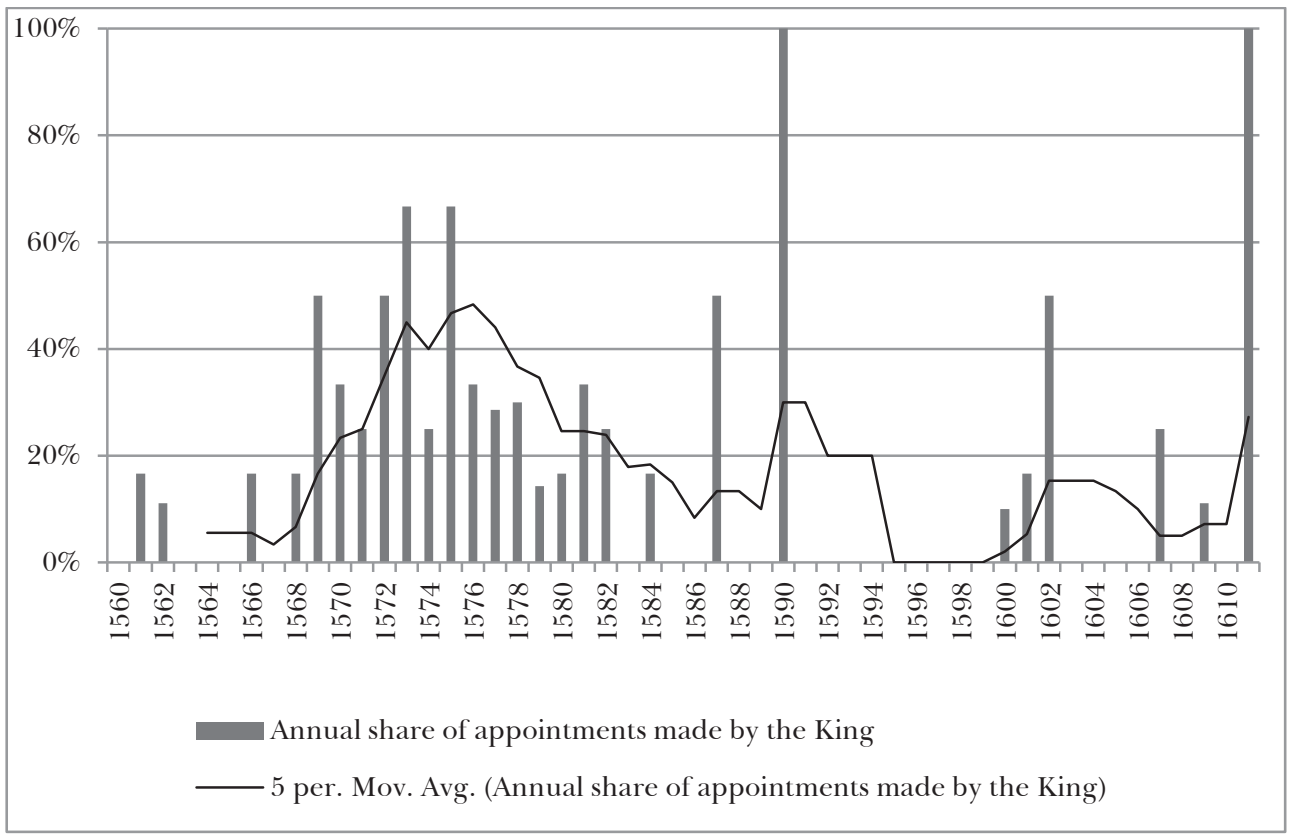

Figure 4: Temporal variation in appointments made by the King (percentage value). Source: CDB 2015.

As the figure shows, the proportion illustrates the exception situation in the $1570 \mathrm{~s}$ in appointments made by the King (note especially the moving average that illustrates the average share of appointments made by the King within five years). In 1568 John III was crowned after a brief rebellion in which Eric XIV, now suffering from mental illness, was deposed (Roberts 1968: 236-239; Karonen 2014: 99100). The rising eagerness to participate in the clerical appointment process might be explained by the fact that it was important to the new King to take control of certain parts of the realm by controlling important posts, such as pastoral posts. However, John, as a former Duke of Finland, could rely on the support of the local elite and thus he did not need to resort to violence to take control of Finland (Hiljanen forthcoming).

In his religious conviction, the newly crowned King differed from his father and brothers: Eric showed an interest in the writings of Melanchthon and Calvin, while John was inclined towards Catholicism partly as a political strategy. Charles for his part was a confirmed Lutheran; sometimes suspected of Calvinism (Ericson 2004: 187, 191-193, 212; Hedberg 2009: 220, 228-229; Lappalainen 2009: 36-37; Nyman 2009: 160).

From a confessional perspective, the change in the clerical appointment process during the 1570s is intertwined with the Counter-Reformation in the north. The religious peace achieved in Augsburg in 1555 offered the churches time to gather their forces and to polish their own religious message. With the advent of 
the 1570s, the Catholic Church had recovered from the first shocks of the Reformation and planned to retake the areas that had adopted the reformed religion. Sweden was one of these realms, while Poland-Lithuania was the stronghold of the Counter-Reformation in the north. The fact that John III was married to the Polish Princess Catherine Jagiellon makes the situation rather complicated. In the marriage the counter-reformists in Poland-Lithuania perceived an opportunity to pull Sweden back into the fold of Rome, but the Counter-Reformation in Sweden never really gained any ground, at least not during John's reign (Roberts 1968: 332-333; Schilling 1992: 222-223, 226, 242; Harrington and Walser Smith 1997: 82; Lappalainen 2009: 45).

There are different religious considerations that shed light on the CounterReformation in Sweden in practice, and which also illustrate the tightening grip of John over the Church, as seen in Figure 4. Perhaps the most important of these has to do with the new liturgy which the King tried to introduce. The first step in this was taken in 1575 with the publication of the Nova Ordinantia (New Order). A year later the New Liturgy (commonly known as the Red Book) was published and introduced throughout the Church. These changes were neither purely Lutheran nor Catholic, but more or less a mixture of both. For example, according to the Red Book, the liturgy should combine the Swedish reformed service and the Catholic mass. John III's intention was ambitious and embracing: he wanted to unite the Catholic and Lutheran churches and he even negotiated with Rome about his plans, but the Pope never accepted John's demands and his religious standpoint and towards the end of the 1570s their negotiations soon broke down. Yet the Counter-Reformation in the North did not end but was merely halted. Instead of John, the Counter-Reformists put their faith in his son, Sigismund, who had received a Catholic education, and who one day would be crowned King of Sweden (Paarma 1980: 224-225; Buchholz 2003: 196-197, 206; Ericson 2004: 196197; Lappalainen 2009: 41-42, 45-49).

Liturgical reforms caused religious dissatisfaction among the clergy, especially in Sweden, where the professors of Uppsala University were the main opponents of reform. The King used clerical appointments as a means to promote the new liturgy: he replaced clergymen opposed to it with men who accepted the new liturgy. In Finland the reception of the new liturgy was somewhat more positive than in the western parts of the realm (Buchholz 2003: 204-205; Ericson 2004: 201; Hedberg 2009: 221-222; Lappalainen 2009: 41-42; Hiljanen forthcoming). However, the King had to dismiss some clergymen from the Finnish pastoral posts, too, and Figure 4 suggests that the King took control of the clerical appointment process in Finland. Thus, it is plausible that the Finnish clergymen were reluctant to comply with the liturgical reforms but the King's removal of the dissenters made pastors in Finland more receptive towards the new liturgy.

John III's eagerness to depart from ecclesiastical norms reveals his attitude towards the clerical appointment process and the Counter-Reformation. According 
to the Church ordinance of 1571, the clerical appointments were the province of the Church, and John III nominally accepted this, but the reality was different: Figure 4 illustrates that he intervened in the clerical appointments more than ever (Appelberg 1896: 68; Holmquist 1933: 110; Heldtander 1955: 18; Paarma 1980: 371-373).

In addition to liturgical reforms, the increasing number of appointments made by the King might be explained also by the governmental development that began in 1570. That year war against Russia broke out and lasted until 1595 (the war is known as the Russo-Swedish War 1570-1595). Finland was especially an important support area, while the main frontier was in the area of the Baltic. Because of the importance of supporting the war-collecting taxes and calling men to arms-the local government in Finland advanced, which during the 1570s in particular meant a more powerful and comprehensive grip on the part of central government and the King. Later, in the 1580s, the system changed again and some of the local power was restored (e. g. Renvall 1949: 102, 312; Karonen 2014: 101-103). This suggests that perhaps the reason for the King's growing eagerness to appoint pastors was related to changes in governmental structures and ways of governing the state.

All in all, as Figure 4 illustrates, the 1570s was the era when the King's domination over the Church regarding clerical appointments was greater than ever before or after. After that decade, the trend for the King to make appointments decreased to the point at which the King did not appoint any pastors in Finland. John's last attempt to control the Church was in 1590, when he appointed the only pastor to be appointed that year. Hence the King's dominance of the appointment process after the 1570s declined.

At the beginning of the $1600 \mathrm{~s}$, however, the share of clerical appointments by the King again increased. Sweden descended into civil war at the end of the 1590s, with Sigismund, the rightful King, and his supporters fighting against Duke Charles and his forces. The war had a religious undertone because Sigismund was a Catholic. The Church resisted the coronation of Sigismund as they feared that he would reinstate the Catholic religion, but the major opponents of the coronation were both Duke Charles, who had laid a hidden claim to the Crown, and the Councilors of the Realm, high-ranking nobles, who wanted to improve the status of the nobility in the realm. The nobility in Finland, however, supported Sigismund and the Bishop of Turku and the majority of the clergy in Finland gave the King their tacit allegiance (Roberts 1968: 229-231; Paarma 1980: 429-440; Karonen 2014: 103-106, 119).

The war itself and all the circumstances leading up to it are complicated. However, during the hostiles, Charles was proclaimed regent of the realm in 1597, but in reality he gained power soon after John III had died and Sigismund was crowned (1592) because dual monarch spent a lot of time in Poland-Lithuania. Finally, in 1599, Sigismund was deposed as King of Sweden and Charles seized 
the throne although he was not formally crowned until $1604 .^{3}$ After Charles and his supporters had won the war, he purged the opposition: many nobles who had supported Sigismund fled the country, some were executed. The Finnish clergy also bore the brunt of Charles' wrath: During the war Charles threatened to replace pastors in Finland with Swedish clergymen loyal to the Duke, but this never happened. Nevertheless, in the meeting of the estates in Linköping in 1600, the Bishop of Turku (Ericus Sorolainen) and the Finnish clergy were accused and condemned: bishop Sorolainen lost his see for some years and the clergy in Finland had to pay extra taxes (Lehtinen 1961: 163-168; Paarma 1980: 429-440; Karonen 2014: 103-121).

Even though the number of clerical appointments made by the King rose in the first decade of the 17 th century, given the tragic events at the end of the 1500 s, the increase seems low. It seems that Charles used clerical appointments to take control of the Church less than, for example, did John III. Was the status of the Church in society in the beginning of the 17th century so low that the King did not feel the need to control its agents? If so, it contradicts at least the main claim of this article concerning the role of clerical appointments in policymaking.

The Swedish historian Sven A. Nilsson has stated that during the reign of Gustavus Adolphus (1611-1632), when the Swedish military state was built up, every official-including the pastors-was harnessed to the war effort so that the army could continue victorious (Nilsson 1990: 234-235). In addition, Marko Hakanen and Ulla Koskinen have studied the boundaries of the personal agency of the Councilors of the Realm in the 16th and 17th centuries. They suggest that the purge carried out by Charles at the beginning of the 17 th century demarcated the limits of agency of the councilors. This meant a new kind of policymaking that started to revolve around the King; during the 16th century the councilors had united against the King (Hakanen \& Koskinen forthcoming).

In light of the views of Nilsson as well as Hakanen and Koskinen, the small number of clerical appointments made by Charles does not perhaps illustrate the loosening grip of the King within the Church or the lost status of the Church in society. Instead, it shows that policymaking and governing in general did indeed change at the beginning of the 17th century. Now the King could use different political strategies to control the Church and local society, and that control of the clerical appointment process was no longer so important. This change meant that religion ceased to be a driving force of competition within the Swedish realm as it had been in the 16th century. However, given the events in Europe in general, especially later in the 17th century, religion had a huge impact on foreign policy and competition between states. Thus the role of religion in politics and society in

3 I have calculated-for the sake of clarity-that Charles reigned from 1600 onwards. For example, Werner Buchholz claims that Charles was practically King of Sweden from 1600 onwards even if he was only crowned in 1604 (Buchholz 2003: 213). 
Sweden changed: in the 16th century it was a divider, later it was a unifying factor in the realm.

\section{The Power Vacuum Fills Up}

The share of clerical appointments made by the King gives only a one-sided picture of the topic of this article: when two parties compete, there are winners and losers. As the King was not the only authority who could intervene in the clerical appointment process, one has to study the appointments made by other authorities to form an overall impression of the limits of the King's power over the Church. As already noted, other authorities appointed 33 (cca. 12\%) pastors during the period in question; Figure 5 presents the share of appointments made by other authorities relative to all appointments made.

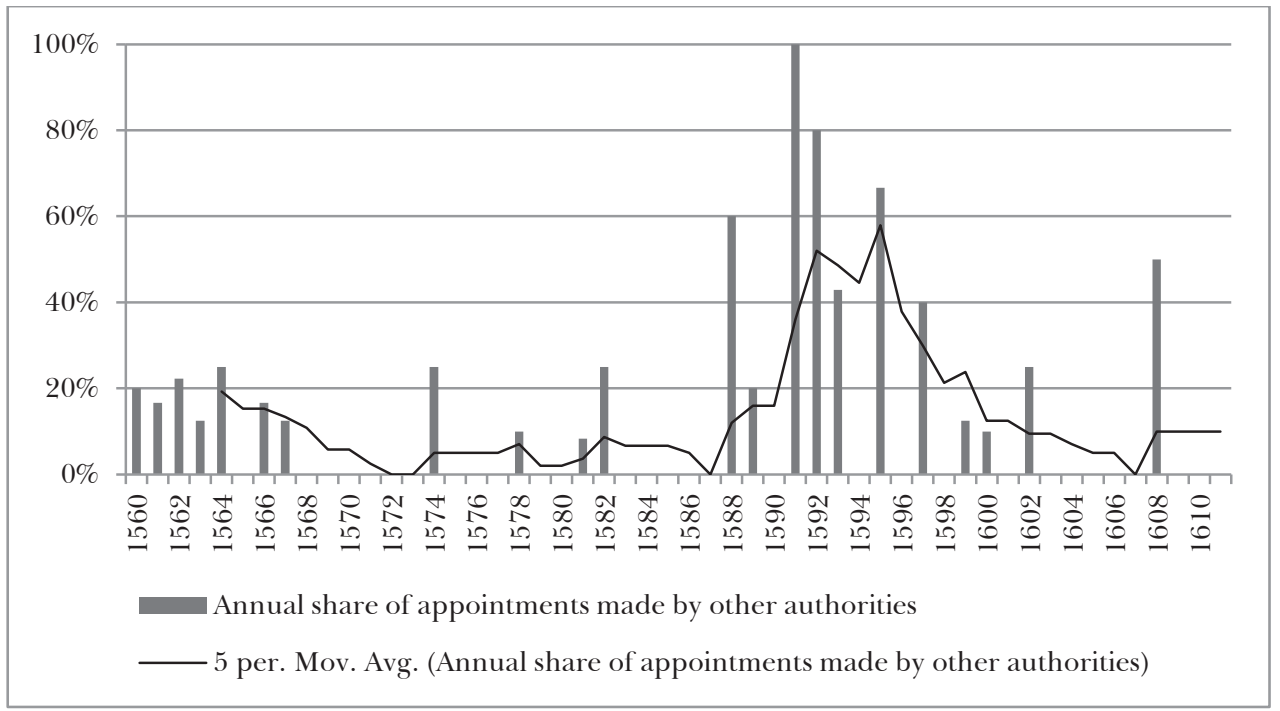

Figure 5: Temporal variation in appointments made by other authorities (percentage value). Source: CDB 2015.

As Figure 5 shows, the shares of clerical appointments made by other authorities were high especially in two different eras. The first of these was the first part of the 1560s, when other authorities appointed approximately one fifth of pastors in the Diocese of Turku. The role of Duke John in particular is significant as he appointed about half of those pastors appointed by other authorities, while the Bishop of Turku appointed the other half (CDB 2015).

The role of John is hardly surprising. John as Duke of Finland was the supreme local government authority in the area and entitled to participate in governmental decisions such as clerical appointments. However, participation in clerical appointment processes was not self-evident for the dukes. Especially when 
the dispute between Duke John and Erik XIV gained momentum, the King at the meeting of estates in Arboga in 1561 pushed through a pact curtailing the power of the dukes. For example, the new instructions stated that the dukes could participate in the clerical appointment process only in the most important parishes, and could nominate only chaplains, not pastors. As Figures 4 and 5 illustrate, this decision was not effective: both the King and Duke John participated in clerical appointment processes although the share of the Duke is higher. The dispute between the King and Duke John culminated in invasion in 1563, when the King and his troops marched to Turku and arrested John; this, of course, brought to an end to the appointments made by Duke John (Appelberg 1896: 63-64; Heldtander 1955: 17; Paarma 1980: 368; Karonen 2014: 92-98).

Another era when the large number of clerical appointments made by other authorities centres around the 1590s. As shown in Figure 5 the number around the 1590s is much greater than in the 1560 s. The rising number of appointments by other authorities in the 1590s suggests that the power vacuum formed because King Sigismund did not appoint any pastors was filled. Otherwise the rising share of other authorities is explained by the fact that the ongoing war with Russia forced Sweden to develop its administration, thus other governmental authorities took charge of decisions (Renvall 1949: 126-127; Karonen 2014: 102; Lappalainen 2009: 68, 146).

The death of John III, Sigismund's rise to power in Sweden and Charles' growth into a full and legitimate power-player affected the clerical appointment processes in the 1590s. The Catholic faith of Sigismund inhibited his prospects of ascending to the Swedish throne without special dispensations. Duke Charles and the high nobility (Councilors of the Realm) were especially anxious to ensure that Sigismund would not succeed to the throne without arrangements that would increase their power and wealth. Charles and the councilors called a meeting in Uppsala in 1593, where the religion of the realm and other circumstances would be decided. The estate of the Clergy had its own goal to promote in Uppsala: it sought greater freedom from the steering of the King and nobles. For example, the clergy claimed that pastoral appointments ought to be handled as the internal affair of the Church under the bishops and the administration of the dioceses. This demand was never fulfilled, but the power of the bishops still increased in terms of clerical appointments (Appelberg 1896: 90; Holmquist 1933: 120; Heldtander 1955: 20; Roberts 1968: 327, 331-336, 340, 346-349; Paarma 1980: 377379; Karonen 2014: 104).

However, the Uppsala assembly addressed not only religion. In Uppsala, Charles and the Councilors of the Realm wanted to make sure that they held the major power when the King was in Poland-Lithuania. In fact, during his absence, Duke Charles and the Councilors formed a rather independent local government, although all the major decisions required the royal assent. In practice this arrangement did not satisfy the power-hungry Duke: as soon as the King Sigismund 
returned to Poland-Lithuania after his coronation in 1594, Duke Charles called a meeting of the estates, where he was designated regent of the realm. Later the situation escalated into an intense debate between the King, the Duke and the councilors in which the Councilors of the Realm relented and did not support the mounting claims of Charles (Roberts 1968: 328-331, 341, 344, 349-353, 356-364; Karonen 2014: 104-106).

Charles' actions led to civil war (1596/7-1598) between the King and his supporters and Duke Charles and his adherents (mostly men from his duchy). The war divided the Swedish realm geographically: Finland was the most important area of support for King Sigismund while mainland Sweden was under the control of Charles. To prevail in the struggle it was important for Duke Charles to gain control of Finland; to achieve this he implemented various strategies. For example, Charles provoked the peasants in Ostrobothnia, who were already suffering hardship due to the agricultural recession and the fact that the army was still entitled to free quartering upon their lands even if the war with Russia was over, to attack against Klas Fleming, the omnipotent governor of Finland who was endlessly loyal to the Crown, and his troops. This war is known as the Club War (1596-1597). It was an independent part of the civil war-a sort of prologuealthough the main troops of Sigismund or Charles were not involved (Roberts 1968: 337-338, 366, 371-372; Karonen 2014: 106-112).

Duke Charles had other means to influence events in Finland, and apparently one of these was the filling of administrative posts. In this pastors were key agents because they administered the parishes, and, together with the bailiffs, they represented government at the local level. In addition, the pastors were in a position to control their parishioners and influence their opinions (Suolahti 1919: 64, 75, 121-122; Paarma 1980: 426; Malmstedt 2002: 73-74; Hallenberg 2012: 113, 126, 132). By controlling the pastors Charles could control the people. Moreover, Duke Charles tried to take control of the chapter of the Diocese of Turku. For example, he appointed Gregorius Martini Teet as the pastor of Turku parish and Henricus Canuti as the cathedral dean. Both were staunch Lutherans and loyal to Charles. In addition, both the pastor of Turku parish and the cathedral dean were members of the chapter, which was in charge of the ecclesiastical affairs in the diocese together with the bishop; the chapter engaged, for example, in making clerical appointments. Thus, by filling the chapter with loyal adherents, Duke Charles could rely on these men to further his interests in ecclesiastical affairs. (CDB 2015; see also Hiljanen forthcoming).

All in all, the turmoil of the 1590s caused by the civil war also affected the clerical appointments process. The nature of the clerical appointments made suggests that the seeds of civil war were sown during the first part of the 1590s, when the power shifted from the Crown to the other authorities, while the war itself broke out as late as 1596. On a more general level, Figure 4 suggests that during exceptional periods (civil war at the end of century and events leading up to it, and the 
beginning of the 1560s when the Duchy of Finland with John as Duke was still functioning) the role of other authorities grew at the expense of the King's role. This for its part suggests that the role of the Crown within the church and ecclesiastical decisions in general was not self-evident but it was dependent on the political reality of the realm.

\section{Conclusion: The Limits of the Power of the Crown}

This article examined the limits of power of the Crown over the Church in the latter part of the 16th century and the first decade of the 17th century in Sweden. The aim was to ascertain the extent of the King's chances to intervene in the clerical appointment process. This process has been defined as an important part of ecclesiastical administration because it was through this that the Church selected its agents, and more generally, members of the Estate of the Clergy. Controlling the process did not only affect the Church: religion and politics were interwoven, and also tied to general administration. Thus the process was by no means insignificant.

The Kings of Sweden appointed altogether 41 of the 267 pastors appointed between 1560 and 1611; in percentages, this is about $15 \%$. This proportion is rather small and I contend that it indicates no dominance by the Crown over the Church. However, scrutiny of the percentages reveals a more complex reality. First of all, as we have seen, different Kings appointed differing numbers of clergymen during their reigns. John III was active in this; he appointed almost every fourth (cca. 24\%) clergyman appointed in John III's reign, while Sigismund did not appoint any pastors during his reign as a King of Sweden. Hence it would be hasty to conclude that the King was or was not active in the clerical appointment process, and thus in ecclesiastical life in general. This merits detailed investigation.

One way to gain a detailed view of the topic is to study the temporal and spatial context in which the King made the appointments. The article claims that the large proportion of the appointments made by John III is-at least partiallyexplained by the new ecclesiastical policy, which was related to a more general phenomenon in Europe: the Counter-Reformation. Other studies suggest that the clergy and especially those in the western part of the Kingdom opposed John's reforms and therefore the King needed to gain a firmer hold over the clerical appointments process. Even though the new liturgy did not cause as much opposition among the clergy in Finland as in Sweden, the fairly large number of appointments made by the King suggests that the process of introducing the new liturgy was not simple in the eastern part of the realm, either. It is possible that the large proportion of appointments that the King made in Finland accounts for the minor opposition to liturgical reforms among the Finnish clergy. This claim is based on the assumption that the clergy in Finland might not have been more or less favorably disposed towards the new liturgy as the clergy in Sweden, but the clerical replacements arranged by the King made the Finnish clergymen depend- 
ent on the Crown. Whatever the truth is, the Crown's control over the Church was greater than ever during the 1570 s.

The increase in the proportion of appointments made by the King at the end of the era tells a similar, but not identical story. In the last decade of the 16 th century and the first decade of the 17th century, Duke Charles revolted and seized power. Above it has been suggested that because of this, it was important for Charles to be able to fill the governmental posts (such as those of pastors) at local level, especially in Finland, which was a strong power base for King Sigismund. However, compared to the numbers during the 1570s, the proportion of clergymen appointed by Charles is fairly small. Due to this, and the fact that Charles consolidated the power within the realm, for example by executing opponents to his policy, this article claims that the policymaking where participating in the clerical appointing process started to lose its meaning and the Crown used other strategies to consolidate its power. All this suggests that the role of confession changed at the beginning of the 1600s: During the reign of Charles IX, confession started to lose its position as a driving force of separation in domestic policy, and the realm became 'purely' Lutheran. ${ }^{4}$ This suggestion corroborates with the studies of the confessionalization paradigm and the common knowledge of the 16th and 17th century history of Sweden. However, in this article I have presented evidence only from the eastern part of the realm. To test and finally verify these statements, we need comparative data from different parts of the realm and more studies in general.

Finally, when one party gains more power, others lose it. Thus to study the changes in the distribution of power, one must research not only winners but also losers. As already implied above, perhaps the greatest loss of power in 16th century Sweden was that sustained by the Church; in the Reformation the King usurped power and wealth from the Church. However, as the Figures (especially 5) above illustrate, this situation did not prevail for the whole of the century. By comparing Figures 4 and 5, we can see that the shares of the appointments made by both the King and other authorities are somewhat inversely proportional-e. g. one falls as the other rises. This, I argue, affords fairly indisputable proof that the King's power over the Church-and perhaps over the whole administration-in Sweden during the latter part of the 16th century was not a self-evident truth. Instead it suggests that the ecclesiastical situation within the realm was disarranged and the King's power was challenged, especially during the 1590s, when the whole situation in the realm was disorganized. In addition, the notion suggests that if the King's grip loosened, other authorities took advantage of the situation and tried to gain more power. Of course, this is not the whole picture, because 
there may have been some genuine delegation of power, which might manifest in the figures as decreasing numbers of appointment made by the King, but given the nature of the process during the $1590 \mathrm{~s}$, delegation might have led to real takeover. ${ }^{5}$

\section{Bibliography}

\section{Sources}

Clergy database 2015 (CDB)

\section{Literature}

Appelberg KA (1896) Bidrag till belysning af sättet för prästtjänsternas besättande $i$ Finland frän reformationen till af 17:de seklet. Doctoral Thesis, University of Helsinki.

Asche M \& Schindling A (eds) (2003) Dänemark, Norwegen und Schweden im Zeitalter der Reformation und Konfessionalisierung. Nordische Königreiche und Konfession 1500 bis 1660. Münster: Aschendorff Verlag.

Buchholz W (2003) Schweden mit Finnland. In Asche M and Schindling A (eds) Dänemark, Norwegen und Schweden im Zeitalter der Reformation und Konfessionalisierung. Nordische Königreiche und Konfession 1500 bis 1660. Münster: Aschendorff Verlag, pp. 107-243.

Brilkman K (2013) Undersåten som förstod. Den svenska reformatoriska samtalsordningen och den tidigmoderna integrationsprocessen. PhD Thesis, University of Lund.

Cederlof J (1934) Det Finländska prästerskapets ekonomiska ställning intill sjuttonde seklet. Helsinki: Svenska litteratursällskapet i Finland.

Czaika O (2007) Die Konfessionalisierung im Schwedischen Reich. In Ketola M and Laine T (eds) Suomen kirkkohistoriallisen seuran vuosikirja 97, pp. 73-98.

Ericson L (2004) Johan III. En biografi. Lund: Historiska media.

Hakanen M \& Koskinen U (forthcoming) Counselors Limits of Agency in Sweden in the Age of Greatness (working title). In Hakanen M and Karonen P (eds) Personal agency in the Swedish Age of Greatness 1560-1720 (working title).

Hallenberg M (2012) Församlingspräst i det Svenska riket under 1500-talet. Traditionell auktoritet under omförhandling. In Letzter EM (eds) Auktoritet $i$ förvandling. Omförhandling av fromhet, lojalitet och makt i reformationens Sverige. Uppsala: Historiska institutionen, Uppsala University, pp. 113-134.

Hansen LI, Heiseldal Bergesen R \& Hage I (eds) (2014) The Protracted Reformation in Northern Norway. Introductory Studies. Stamsund: Orkana forlag.

$5 \quad$ Acknowledgement: Svenska Litteratursällskapet i Finland (Society for Swedish Literature in Finland) and the Jalmari Finne Foundation supported this study. 
Harrington JF \& Walser Smith H (1997) Confessionalization, Community, and State Building in Germany, 1555-1870. The Journal of Modern History 69(1): 77101.

Hedberg L (1995) Företagfursten och framväxten av den starka staten. Hertig Karls rerusrsexploatering $i$ Närke 1581-1602. Doctoral Thesis, University of Örebro, Sweden.

Hedberg L (2009) Karl IX. Företagarfursten E̋ envåldshärskaren. Stockholm: Prisma. Heldtander T (1955) Prästtillsättningar $i$ Sverige under stormaktstiden. Tiden före kyrkolagen 1686. Uppsala.

Hernroth U (1989) Studier rörande Prästtillsättningen $i$ Sverige och Danmark efter reformationen. Göteborg: Tre böcker.

Hiljanen M (forthcoming) Servants of the Crown or Trustees of the People? Personal Agency among the Local Clergy in the 16th century Finland (working title). In Hakanen M and Karonen P (eds) Personal agency in the Swedish Age of Greatness 1560-1720 (working title).

Holmquist H (1933), Tillsättningar av gäll i Sverige under reformationsårhundradet. Historisk tidskrift 1933: 90-128.

Karonen P (2014) Pohjoinen suurvalta. Ruotsi ja Suomi 1521-1809. Helsinki: SKS.

Laasonen P (1983) Papinvirkojen täyttö Suomessa myöhäiskaroliinisena aikana 16901713. Helsinki: Suomen kirkkohistoriallinen seura.

Lappalainen M (2009) Susimessu. 1590-luvun sisällissota Ruotsissa ja Suomessa. Helsinki: Siltala.

Lavery J (2012) A Frontier of Reformation. Finland in the Reformation Era. In Czaika $\mathrm{O}$ and Holze $\mathrm{H}$ (eds) Migration und Kulturtransfer im Ostseeraum während der Frühen Neuzeit. Stockholm: Kunliga biblioteket, pp. 60-75.

Lehtinen E (1961) Hallituksen yhtenäistämispolitiikka Suomessa 1600-luvulla (1600-n. 1680). Doctoral thesis, University of Helsinki.

Lindström P (2000) Från konsensus till majoritet: Bönder, prästval och politisk kultur 1650-1800. Historisk tidskrift 2000(2): 207-225.

Lindsröm P (2003) Prästval och politisk kultur 1650-1800. Doctoral Thesis, University of Umeå.

Lipset SM \& Rokkan S (1967) Cleavage Structures, Party Systems, and Voter Alignments: An Introduction. In Lipset SM and Rokkan S (eds) Party Systems and Voter Alignments: Cross-National Perspectives. New York: The Free Press, pp. 1-64.

Malmstedt G (2002) Bondetro och kyrkoro. Religiös mentalitet $i$ stormaktstiden Sverige. Lund: Nordic Academic Press.

Markkola P \& Naumann IK (2014) Lutheranism and the Nordic Welfare Sates in Comparison. Journal of Church and State 56(1): 1-12.

Matinolli E (1955) Turun hiippakunnan papinvaalit ja papinvirkojen täyttäminen aikakautena 1721-1808. Sosiaalihistoriallinen tutkimus. Doctoral Thesis, University of Turku. 
McCallum J (2010) Reforming the Scottish Parish: The Reformation in Fife, 1560-1640. Farnham: Ashgate.

Montgomery I (1972) Värjostånd och lärostånd. Religion och politik $i$ meningsutbytet mellan kungamakt och prästerskap i Sverige 1593-1608. Uppsala: Acta Universitatis Upsaliensis.

Nilsson SA (1990) De stora kirgens tid. Om Sverige som militärstat och bondesamhälle. Uppsala: Acta Universitatis Upsaliensis.

Nummela I (2003) Asutus, pelto ja karja. In Rasila V, Jutikkala E, and MäkeläAlitalo A (eds) Suomen maatalouden historia 1. Perinteisen maatalouden aika esihistoriasta 1870-luvulle. Helsinki: SKS, pp. 133-158.

Nyman M (2009) Hävinneiden historia. Katolista elämää Ruotsi-Suomessa Kustaa Vaasasta kuningatar Kristiinaan. Helsinki: Katolinen tiedotuskeskus.

Reinhard W (1999) Pressures towards Confessionalization? Prolegomena to a Theory of the Confessional Age. In Dixon CS (eds) The German Reformation. The Essential Readings. Oxford: Blackwell, pp. 172-195. Originally published as Reinhard W (1983) Zwang zur Konfessionalisierung? Prolegomena zu einer Theorie des konfessionellen Zeitalters. Zeitschrift für Historische Forschung 10: 257-77.

Renvall P (1949) Kuninkaanmiehiä ja kapinoitsijoita Vaasa-kauden Suomessa. Helsinki: Kustannusosakeyhtiö Tammi.

Roberts M (1968) The Early Vasas. A History of Sweden, 1525-1611. Cambridge: University Press.

Sandahl M (1966) Prästval $i$ Sverige mot kulturell och social bakgrund. Falköping: Gummerssons.

Schilling H (1992) Confessionalization in the empire: religious and societal change in Germany between 1555 and 1620. In Schilling H (ed) Religion, political culture and the emergence of early monerd society. Essays in German and Dutch History. Leiden: Brill, pp. 205-245.

Suolahti G (1919) Suomen papisto 1600- ja 1700-luvuilla. Porvoo: WSOY.

Tolley B (1995) Pastors and Parishioners in Württemberg during the Late Reformation, 1581-1621. Palo Alto, CA: Stanford University Press.

Paarma J (1980) Hiippakuntahallinto Suomessa 1554-1604. Doctoral Dissertation, University of Helsinki.

Po-Chia Hsia R (1989) Social Discipline in the Reformation: Central Europe 1550-1750. London and New York, NY: Routledge.

Väänänen K (1990) Paimenmuistot, papiston henkilöhistoriantutkimuksen perusteokset. Suomen kirkkohistoriallisen seuran vuosikirja 79: 175-183. 